\title{
Patterns of Virulence in Natural Populations of Puccinia coronata on Wild Oat in Israel and in Agricultural Populations on Cultivated Oat in the United States
}

\author{
K. J. Leonard, Y. Anikster, and J. Manisterski
}

First author: U.S. Department of Agriculture-Agricultural Research Service, Cereal Disease Laboratory, University of Minnesota, St. Paul 55108; and second and third authors: Institute for Cereal Crops Improvement, Tel Aviv University, Ramat Aviv 69978, Israel. Current address of K. J. Leonard: Plant Pathology Department, University of Minnesota, St. Paul 55108. Accepted for publication 21 January 2004.

\begin{abstract}
Leonard, K. J., Anikster, Y., and Manisterski, J. 2004. Patterns of virulence in natural populations of Puccinia coronata on wild oat in Israel and in agricultural populations on cultivated oat in the United States. Phytopathology 94:505-514.

Crown rust (Puccinia coronata) in indigenous populations of Avena sterilis has been cited as an example of stability of wild pathosystems that consist of natural mixtures of resistance and virulence. This study confirmed that virulence/avirulence polymorphisms in $P$. coronata on A. sterilis in Israel are highly diverse and that super races do not dominate. Isolates of $P$. coronata from Israel in 1991 to 1996 were polymorphic for virulence to 35 of 36 differential oat lines with resistance genes from A. sterilis. On average, isolates of $P$. coronata were more highly virulent to differentials with $P c$ genes from A. sterilis accessions from Israel than
\end{abstract}

ABSTRACT to differentials with $P c$ genes from other countries. Isolates from Israel also were more virulent on average to 10 additional differentials with $P c$ genes derived from $A$. sativa than to differentials with $P c$ genes from $A$. sterilis. Frequencies of virulence were usually higher in collections of $P$. coronata from Israel than in collections from cultivated oat in the United States, even though several of the $P c$ genes in the differentials have been used extensively in American oat cultivars. Mean virulence complexity of $P$. coronata from eight regions of Israel was not correlated with the distribution of resistance among collections of A. sterilis from previous surveys in the same areas, probably because pathogen migration between regions within Israel is sufficient to obscure effects of selection locally.

Additional keywords: balancing selection, center of origin, host-parasite coevolution.
Crown rust of oat caused by Puccinia coronata is the most destructive disease of cultivated oat (Avena sativa) in the United States and many other countries that produce oat commercially. Crown rust also is endemic on wild populations of $A$. sterilis, the progenitor of the cultivated A. sativa, and other wild oats in the Mediterranean region. A. sterilis occurs abundantly in Israel and is regularly infected by $P$. coronata (35). An alternate host for $P$. coronata, Rhamnus palaestina, also is abundant in Israel and is infected regularly with aecia of $P$. coronata from December to April. Teliospores produced in April or May remain dormant during the hot Mediterranean summer and germinate to produce basidiospores that infect $R$. palaestina as new leaves develop in response to winter rains (35). $R$. cathartica is the main alternate host for $P$. coronata in the United States. In northern states, teliospores produced in late summer remain dormant through the winter and germinate in the spring. Aecia on $R$. cathartica are the source of primary inoculum for oat in northern states, although later influxes of urediniospores from the south also occur in many years (27). In the southern United States, $P$. coronata persists through the winter in the uredinial stage on fall-sown winter oat (27).

$P$. coronata is an ideal pathogen in which to compare patterns of virulence that result from coevolution with wild hosts in natural ecosystems relative to patterns of virulence produced in selection imposed by agricultural systems with managed cultivation and breeding of the host. The natural populations of $P$. coronata

Corresponding author: K. J. Leonard; E-mail address: kurtl@umn.edu

Publication no. P-2004-0322-04R

This article is in the public domain and not copyrightable. It may be freely reprinted with customary crediting of the source. The American Phytopathological Society, 2004. in Israel are essentially free of agricultural influences, because there is little or no cultivated oat production in Israel and neighboring areas of southwestern Asia $(16,35)$. Genes for racespecific resistance to crown rust in natural populations of $A$. sterilis have been widely exploited for breeding resistant cultivars of A. sativa in North America, because of the great diversity of resistance genes in A. sterilis and the ease with which genes may be transferred through hybridization of A. sterilis and A. sativa. Most of the genes for race-specific resistance to crown rust that have been transferred to cultivated oat from A. sterilis were derived from accessions of $A$. sterilis collected in Israel and other countries of the Mediterranean region in the 1960s and early 1970s (28). Lines of A. sativa with individual resistance genes from these accessions are available for screening collections of $P$. coronata for virulence against the resistance genes from A. sterilis, a host on which populations of $P$. coronata have coevolved for thousands of years in Israel.

A. sterilis is absent from the United States except for small areas of California, which is isolated from the main areas of U.S. oat production (13). The wild oat of the Great Plains, A. fatua, was introduced from Europe, as was A. sativa. A. sativa apparently was domesticated from $A$. sterilis, which was brought into Europe from Asia Minor as a weed mixed with emmer wheat (16). The populations of A. fatua in the United States resemble early cultivars of $A$. sativa in their relative lack of crown rust resistance genes (18; K. J. Leonard, unpublished data), which are abundant in A. sterilis. Thus, the North American populations of $P$. coronata have evolved in response to management and breeding of cultivated oat without selection pressure from natural resistance in wild oat populations, whereas the Israeli populations of $P$. coronata coevolved with a wild host with little or no influence of cultivated oat on the distribution of virulence (35). 
In this study, we compare overall virulence complexity and the frequencies of individual virulence factors in the natural populations of $P$. coronata in Israel with virulence complexity and virulence frequencies on cultivated oat in the Southern Plains and Northern Plains of the United States. The comparisons involved virulences that correspond to many different crown rust resistance genes derived from A. sterilis, including some that have been used extensively in cultivated oat in the United States as well as others that have been used sparingly or not at all in cultivated oat. The objective was to test whether virulence in naturally coevolved pathogen populations is generally more diverse than virulence in populations on agricultural crops or whether the diversity of resistance in a wild host population tends to select super races of the pathogen.

\section{MATERIALS AND METHODS}

Oat leaves heavily infected with $P$. coronata were collected in Israel in 1991, 1992, 1993, 1994, and 1996 and sent to the U.S. Department of Agriculture-Agricultural Research Service Cereal Disease Laboratory at the University of Minnesota for testing. In 1991 to 1994, a single sample was collected from each of a large number of sites throughout Israel. Each sample consisted of several rusted host leaves infected with the uredinial stage of $P$. coronata. A total of 130 isolates were obtained from samples collected in Israel in 1991 to 1994; 122 were from A. sterilis, 6 from A. barbata, and 2 from A. sativa (grown at the Research Station at Bet Dagan). In 1996, samples were collected at only two locations, (i) a site heavily populated with A. sterilis in the Menashe Plateau and (ii) an experimental planting of $A$. sativa near Tel Aviv in the Central Coastal Plain (Fig. 1). From the 1996 collections, 22 isolates of $P$. coronata were obtained from A. sterilis from the Menashe Plateau and 26 isolates were obtained from A. sativa at Tel Aviv.

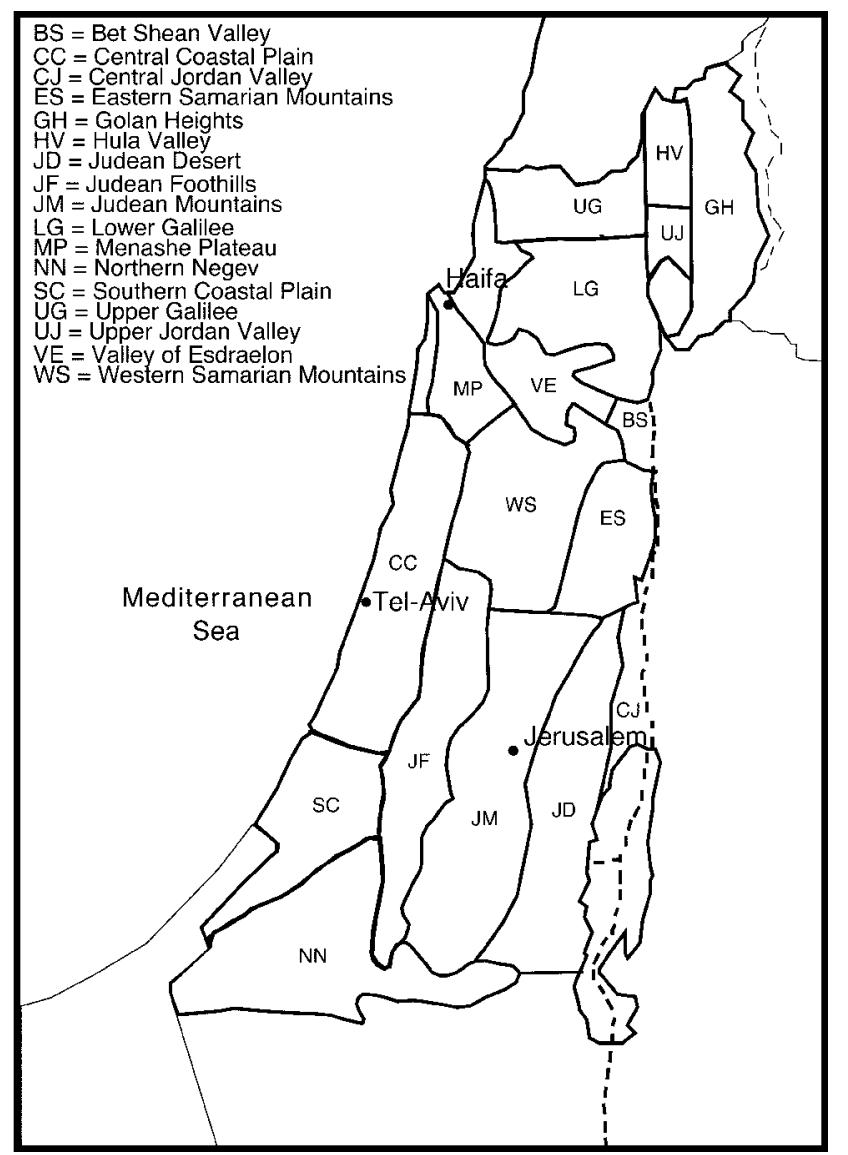

Fig. 1. Areas of Israel from which isolates of Puccinia coronata were obtained.
At the Cereal Disease Laboratory, urediniospores were collected from the infected oat leaves with a cyclone spore collector, suspended in light mineral oil, and sprayed onto 7- to 9-day-old seedlings of oat cv. Marvellous, which is susceptible to all known races of oat crown rust. The inoculated seedlings were left for 30 min to allow the oil to evaporate. Then they were incubated overnight in a dew chamber at $18^{\circ} \mathrm{C}$ before being returned to the greenhouse at 18 to $28^{\circ} \mathrm{C}$. In the greenhouse, the infected seedlings were maintained in polyethylene isolation cells to minimize cross contamination of isolates. When uredinia appeared, a reserve bulk sample of urediniospores was collected from seedlings infected with each field rust sample, and the leaves then were trimmed to leave a single uredinium per sample. The seedlings then were placed in a dew chamber for 2 to $3 \mathrm{~h}$ to stimulate sporulation of any urediniospores scattered on the leaf surface, after which the seedlings were removed from the dew chamber and dried to kill the germinating spores. The trimmed seedlings then were returned to their isolation cells in the greenhouse for several days to allow further sporulation in the remaining single uredinium. Urediniospores were collected from the single uredinial isolates with a cyclone spore collector and increased through one more uredinial generation on Marvellous oat seedlings in isolation cells. Single-uredinial isolates were deposited in longterm storage in liquid nitrogen at the Cereal Disease Laboratory.

The single-uredinial isolates were tested for virulence on 7- to 9-day-old seedlings of three sets of differentials, including (i) 10 differential cultivars used in U.S. surveys from 1955 to 1975 $(21,22)$ and in Israel from 1956 to 1959 (33) and 1976 to 1988 (2), (ii) 26 single- $P c$ gene lines used in the annual oat crown rust virulence surveys at the Cereal Disease Laboratory (18), and (iii) 11 backcross lines from the oat multiline breeding program at Iowa State University (K. G. Frey, personal communication) with unidentified crown rust resistance genes from A. sterilis accessions backcrossed into an A. sativa background (Table 1). Seedlings of this extended differential set were inoculated by spraying them with a suspension of urediniospores of single-uredinial isolates, and the inoculated plants were incubated in a dew chamber as described above. After 10 to 14 days in the greenhouse, the inoculated differentials were evaluated for infection type. Lines with an abundance of large, heavily sporulating uredinia were scored as susceptible; lines with no visible reaction, flecks, or small uredinia surrounded by chlorosis or necrosis and with sparse sporulation were scored as resistant.

The genes $P c-35, P c-39, P c-40, P c-45, P c-46, P c-48, P c-51$, $P c-52, P c-55, P c-57, P c-58, P c-59, P c-60, P c-61, P c-70$, and $P c-$ 71 all came from $A$. sterilis accessions collected in Israel (7-9, $15,20,28) . P c-55$ appears to be allelic and is very similar to $P c-39$ (6), but Bonnett (1) showed that $P c-39$ can be distinguished from $P c-55$ by its greater tendency to lose effectiveness at high temperatures. $P c-36$ is from A. sterilis from Portugal (23). $P c-38, P c$ 56, $P c-63, P c-67$, and $P c-68$ are from A. sterilis from Algeria (7,12,15,37). $P c-54$ is from A. sterilis from Turkey (28). Pc-62 and $P c-64$ are from A. sterilis from Morocco (12,37). Pc-14 is from the Brazilian cv. Ascencao of A. sativa (23).

Isolates of $P$. coronata collected from oat fields and nurseries in the United States in annual crown rust virulence surveys conducted at the Cereal Disease Laboratory starting in 1990 were used in comparisons with isolates from Israel. Collection procedures for the U.S. isolates were similar to those used with the isolates from Israel, but the U.S. isolates were tested only on the Cereal Disease Laboratory set of 22 single- $P c$ gene differential lines. Data from the 1991, 1992, 1993, 1994, and 1996 crown rust survey collections were compared with those from the same years in Israel. Two sets of U.S. isolates were selected for the comparisons representing the Southern Plains (Texas) and the Northern Plains (Minnesota, North Dakota, and South Dakota). The numbers of isolates obtained from these two regions of the United States are within the same range as the numbers of iso- 
lates from Israel, except that few isolates were obtained from Israel in 1993.

In 1992, aecial isolates of $P$. coronata were collected from the St. Paul buckthorn nursery to test whether avirulence on any of the oat differentials would preclude infection of either $R$. cathartica or $R$. palaestina by basidiospores of $P$. coronata. In the buckthorn nursery, overwintered telial straw of oat plants that had been heavily infected with $P$. coronata was placed on top of hedges of $R$. cathartica in the spring as the new leaves began to emerge. Ten potted plants of $R$. palaestina trimmed to produce a new flush of leaves in the greenhouse were moved to positions at intervals along one of the $R$. cathartica hedges at the time that pycnial infections began to appear. When aecia appeared, samples were collected from $R$. cathartica adjacent to the potted $R$. palaestina plants as well as from $R$. palaestina. Aeciospores were applied to 7- to 9-day-old seedlings of Marvellous oat by rubbing aecia over the oat leaves. The inoculated oat seedlings were incubated in the dew chamber overnight and then placed in isolation chambers in the greenhouse. Single-uredinial isolates were obtained by the methods used for collections of $P$. coronata from oat. Isolates derived from aeciospores were tested on the set of 22 single- $P c$ gene differential lines used in the U.S. crown rust virulence surveys.

Virulence frequencies were compared by region and by year of collection. Statistical significance of differences in frequencies of virulence on individual differentials between regions was determined by both the $\chi^{2}$ test adjusted for continuity (31) and by Fisher's exact test for 2-by-2 contingency tables (19). Races based on Simons and Murphy's (30) differential set were determined for isolates from Israel based on descriptive formulas for races 201 to 347 of Simons and Michel (29). Previous surveys in Israel showed that the 276 group and the 264 group of races were the most common races in Israel.

A normalized virulence complexity value was determined for each isolate based on the proportion of differential lines susceptible to that isolate. For the collections from Israel, the 10 Simons and Murphy (30) differentials were excluded from calculations of virulence complexity. Two virulence complexity values were determined, one based on the 26 differentials with known single $P c$ genes plus the 11 lines from the Iowa multiline breeding program and the other only on the 26 differentials with known single $P c$ genes. Collections were compared by mean virulence complexity over all isolates and by distribution of complexity values within collections.

Mean virulence complexity was determined for collections of $P$. coronata from nine areas within Israel (Table 2) and compared between areas. The relationship between virulence complexity and distribution of race-specific resistance among areas within Israel was determined using data on resistance in A. sterilis from Wahl (34). Correlations were calculated between virulence complexity from this study and from frequency of resistance determined by Wahl (34).

\section{RESULTS}

From collections throughout Israel in 1991 to 1994,130 isolates of $P$. coronata were obtained (Table 2). Not all areas in Israel were represented by isolates in each year, and the total number of isolates from most areas was less than 10. Thus, it was not always feasible to compare frequencies of virulence on specific differentials between areas. Isolates from the paired adjacent areas of the Valley of Esdraelon and Bet Shean Valley, Menashe Plateau and Samarian Mountains, and Judean Foothills and Judean Mountains were combined for calculations of mean virulence complexity. In 1996, 26 isolates were obtained from A. sterilis at a site in the Menashe Plateau, and 22 isolates were obtained from experimental plots of $A$. sativa near Tel Aviv. In general, the virulence frequencies of the two sets of isolates from 1996 were more similar to each other than were the overall virulence fre- quencies from different years in Israel (data not shown). Thus, host differences in 1996 had less effect than differences in years of collection on the observed virulence frequencies.

Overall virulence frequencies in Israel are shown by year in Table 3. Virulence frequencies generally were high on all of the Simons and Murphy (30) differentials except for 'Saia', which was resistant to 93 to $100 \%$ of the isolates from individual years. Earlier surveys in Israel with these differentials indicated that the race group including races 276,264 , and similar races, which are virulent on cvs. Anthony, Appler, Bond, Landhafer, Santa Fe, Ukraine, Trispernia, and Bondvic, were the most common races $(2,33)$. In this study, these races comprised 22 of 30 isolates in 1991, 33 of 42 in 1992, 4 of 7 in 1993, 16 of 48 in 1994, and 5 of 46 in 1996. The lower frequency of races in the 276-264 group in 1996 was accounted for by the low frequency (34\%) of virulence on Bond $(P c-3$ and $P c-4)$. With the exception of Bond and the

TABLE 1. Differentials used to assess virulence in Puccinia coronata isolates from Israel and the United States in 1991 to $1996^{\mathrm{a}}$

\begin{tabular}{|c|c|c|}
\hline Number & Variety/line & $P c$ genes \\
\hline$\overline{1}$ & Anthony & Unknown \\
\hline 2 & Victoria & $2,11,12$ \\
\hline 3 & Appler & 1 \\
\hline 4 & Bond & 3,4 \\
\hline 5 & Landhafer & 5 \\
\hline 6 & Santa Fe & $6,7,8,9 \mathrm{c}, 21$ \\
\hline 7 & Ukraine & $3 c, 4 c, 6 c, 9$ \\
\hline 8 & Trispernia & $6 d$ \\
\hline 9 & Bondvic & $2 c, 6 d$ \\
\hline 10 & Saia & $15,16,17$ \\
\hline 11 & D504 & 14 \\
\hline 12 & $P c-35^{\mathrm{b}}$ & 35 \\
\hline 13 & X766 & 36 \\
\hline 14 & $P c-38^{\mathrm{b}}$ & 38 \\
\hline 15 & $P c-39^{\mathrm{b}}$ & 39 \\
\hline 16 & $P c-40^{\mathrm{b}}$ & 40 \\
\hline 17 & $P c-45^{\mathrm{b}}$ & 45 \\
\hline 18 & $P c-46^{\mathrm{b}}$ & 46 \\
\hline 19 & $P c-48^{\mathrm{b}}$ & 48 \\
\hline 20 & $\mathrm{X} 270$ & 51 \\
\hline 21 & $\mathrm{X} 421$ & 52 \\
\hline 22 & $P c-54^{\mathrm{b}}$ & 54 \\
\hline 23 & $P c-55^{\mathrm{b}}$ & 55 \\
\hline 24 & $P c-56^{\mathrm{b}}$ & 56 \\
\hline 25 & D640 & 57 \\
\hline 26 & TAM-O-301 & 58 \\
\hline 27 & TAM-O-312 & 59 \\
\hline 28 & Coker 227 & 60 \\
\hline 29 & Coker 234 & 61 \\
\hline 30 & $P c-62^{\mathrm{b}}$ & 62 \\
\hline 31 & $P c-63^{\mathrm{b}}$ & 63 \\
\hline 32 & $P c-64^{\mathrm{b}}$ & 64 \\
\hline 33 & $P c-67^{\mathrm{b}}$ & 67 \\
\hline 34 & $P c-68^{\mathrm{b}}$ & 68 \\
\hline 35 & H547 & 70 \\
\hline 36 & Y345 & 71 \\
\hline 37 & H548 & Unknown \\
\hline 38 & X117-1964-15-4 & Unknown \\
\hline 39 & $\mathrm{X} 424-2$ & Unknown \\
\hline 40 & $\mathrm{X} 465$ & Unknown \\
\hline 41 & $\mathrm{X} 475$ & Unknown \\
\hline 42 & X537 & Unknown \\
\hline 43 & X543 & Unknown \\
\hline 44 & X716 & Unknown \\
\hline 45 & X721 & Unknown \\
\hline 46 & Y346 & Unknown \\
\hline 47 & Y347 & Unknown \\
\hline
\end{tabular}

a Numbers 1 to 10 are the old standard differentials established by Simons and Murphy (30), numbers 11 to 36 have been used in the United States since 1990 (18), and numbers 12,14 to 19,22 to 24 , and 26 to 34 have been used in Canada (5). Numbers 11, 20, 21, 25, and 35 to 47 are backcross lines from the Iowa oat multilane breeding program in which $P c$ genes from Avena sterilis were backcrossed into cultivated oat backgrounds with various defeated genes for crown rust resistance (K. G. Frey, personal communication).

b Single $P c$ gene backcross lines in Pendek background (5). 
diploid oat Saia, virulence to the other Simons and Murphy (30) differentials occurred at $>50 \%$ in all 5 years.

Collections of $P$. coronata from Israel showed a high level of polymorphism for virulence/avirulence on differentials with known single $P c$ genes (Table 3 ). The only exception was that no isolates virulent to $P c-68$ were found in Israel. Virulence to $P c-68$ was rare in the United States except in 1994, when $20 \%$ of the isolates collected from Texas showed virulence to Pc-68 (Table $4)$. No other $P c$-gene differentials were resistant to all isolates from Israel in any year except 1993, in which only seven isolates were tested. In many cases, the frequencies on specific differentials changed dramatically from year to year. For example, virulence to $P c-45$, which was rare in the United States, rose from $31 \%$ in Israel in 1991 to $94 \%$ in 1996 , and virulence to Pc-64 rose from $27 \%$ in 1991 to $84 \%$ in 1996 .

With respect to the differentials with known single $P c$ genes from A. sterilis, the average frequency of virulence over all years among isolates from Israel was significantly greater $\left(P=7 \times 10^{-6}\right)$ on differentials with $P c$ genes from Israel (i.e., $P c-35, P c-39, P c$ 40, Pc-45, Pc-46, Pc-48, Pc-51, Pc-52, Pc-55, Pc-57, Pc-58, Pc59, $P c-60, P c-61, P c-70$, and $P c-71)$ than on differentials with $P c$ genes from other Mediterranean countries (i.e., $P c-36, P c-38, P c$ 54, $P c-56, P c-62, P c-63, P c-64, P c-67$, and $P c-68)$. This is true $(P=0.00015)$ even if $P c-68$, for which no isolates from Israel were virulent, is removed from the comparison. Considering isolates from individual years, virulence frequencies were higher on differentials with $P c$ genes from Israel than on differentials with $P c$ genes from other countries in $1991(P=0.028), 1992(P=$ $0.003)$, and $1996(P=0.004)$ but not in $1993(P=0.311)$ or 1994 $(P=0.071)$. The average frequency of virulence among isolates from Israel to differentials with $P c$ genes from A. sterilis from Israel was significantly lower than the average frequency of virulence to $A$. sativa differentials ( $P C$ - 14 plus the Simons and Murphy [30] differentials except Saia, which is diploid) in 1991 $\left(P=2 \times 10^{-10}\right), 1992\left(P=5 \times 10^{-7}\right), 1993\left(P=6 \times 10^{-8}\right)$, and $1994(P=0.004)$ but not $1996(P=0.16)$.

Virulence/avirulence also was polymorphic in Israel for all of the differential lines from the Iowa multiline breeding program, which have unidentified genes for race-specific resistance derived from A. sterilis. The most susceptible of these lines, 'X465', was susceptible to 98 to $100 \%$ of the isolates each year except 1994, when just $71 \%$ of the isolates from Israel were virulent on it. The susceptibility of this line is significant, because the Iowa multiline background genotypes had older, defeated crown rust resistance genes from A. sativa. X465 was derived from backcrosses to a line from a 'Clintland' $\times$ 'Garry' cross (K. G. Frey, personal communication). With this background, X465 could have the genes
TABLE 3. Frequencies of virulence in collections of Puccinia coronata from Israel

\begin{tabular}{|c|c|c|c|c|c|}
\hline \multirow[b]{2}{*}{ Differential } & \multicolumn{5}{|c|}{ Percent isolates virulent } \\
\hline & 1991 & 1992 & 1993 & 1994 & 1996 \\
\hline Anthony & 93 & 95 & 100 & 60 & 70 \\
\hline Victoria & 100 & 100 & 100 & 91 & 100 \\
\hline Appler & 97 & 98 & 86 & 80 & 76 \\
\hline Bond & 97 & 95 & 100 & 74 & 34 \\
\hline Landhafer & 100 & 93 & 86 & 65 & 55 \\
\hline Santa Fe & 90 & 98 & 100 & 68 & 74 \\
\hline Ukraine & 100 & 100 & 100 & 81 & 77 \\
\hline Trispernia & 100 & 100 & 71 & 100 & 96 \\
\hline Bondvic & 100 & 100 & 86 & 100 & 89 \\
\hline Saia & 3 & 2 & 0 & 0 & 7 \\
\hline Pc-14 & 77 & 95 & 86 & 90 & 81 \\
\hline$P c-35$ & 59 & 79 & 71 & 53 & 77 \\
\hline$P c-36$ & 40 & 40 & 43 & 4 & 6 \\
\hline$P c-38$ & 22 & 21 & 29 & 47 & 23 \\
\hline Pc-39 & 30 & 50 & 29 & 63 & 94 \\
\hline$P c-40$ & 68 & 95 & 71 & 100 & 94 \\
\hline$P c-45$ & 31 & 59 & 29 & 94 & 91 \\
\hline$P c-46$ & 53 & 69 & 57 & 98 & 94 \\
\hline Pc- 48 & 40 & 48 & 0 & 67 & 70 \\
\hline$P c-51$ & 43 & 67 & 33 & 16 & 34 \\
\hline$P c-52$ & 17 & 19 & 0 & 45 & 21 \\
\hline$P c-54$ & 50 & 74 & 43 & 96 & 91 \\
\hline$P c-55$ & 23 & 48 & 29 & 60 & 91 \\
\hline$P c-56$ & 31 & 10 & 43 & 6 & 9 \\
\hline$P c-57$ & 23 & 52 & 0 & 90 & 89 \\
\hline Pc-58 & 26 & 54 & 0 & 33 & 34 \\
\hline$P c-59$ & 71 & 78 & 50 & 29 & 17 \\
\hline$P c-60$ & 67 & 90 & 71 & 55 & 49 \\
\hline$P c-61$ & 43 & 62 & 57 & 29 & 43 \\
\hline$P c-62$ & 0 & 11 & 14 & 33 & 30 \\
\hline$P c-63$ & 17 & 10 & 14 & 2 & 0 \\
\hline Pc-64 & 27 & 45 & 43 & 84 & 46 \\
\hline$P c-67$ & 40 & 52 & 29 & 51 & 43 \\
\hline Pc-68 & 0 & 0 & 0 & 0 & 0 \\
\hline$P c-70$ & 34 & 55 & 14 & 48 & 72 \\
\hline$P c-71$ & 17 & 45 & 14 & 42 & 59 \\
\hline H548 & 7 & 31 & 0 & 53 & 68 \\
\hline X117-1964-15-4 & 3 & 36 & 57 & 2 & 13 \\
\hline X424-2 & 33 & 12 & 29 & 12 & 4 \\
\hline $\mathrm{X} 465$ & 100 & 98 & 100 & 71 & 98 \\
\hline X475 & 60 & 74 & 57 & 43 & 30 \\
\hline X534 & 37 & 40 & 43 & 4 & 9 \\
\hline X537 & 77 & 79 & 100 & 54 & 43 \\
\hline X716 & 33 & 36 & 57 & 8 & 9 \\
\hline X721 & 93 & 79 & 100 & 33 & 40 \\
\hline Y346 & 83 & 86 & 33 & 67 & 81 \\
\hline Y347 & 37 & 64 & 57 & 49 & 68 \\
\hline No. of isolates & 30 & 42 & 7 & 51 & 48 \\
\hline
\end{tabular}

TABLE 2. Distribution of collections of Puccinia coronata among regions of Israel ${ }^{\mathrm{a}}$

\begin{tabular}{|c|c|c|c|c|c|}
\hline \multirow[b]{2}{*}{ Region } & \multicolumn{5}{|c|}{ Number of isolates } \\
\hline & 1991 & 1992 & 1993 & 1994 & Total $^{\mathrm{b}}$ \\
\hline Golan Heights & 3 & 1 & 0 & 2 & 6 \\
\hline Upper Galilee & 0 & 2 & 0 & 2 & 4 \\
\hline Upper Jordan Valley & 0 & 0 & 0 & 1 & 1 \\
\hline Lower Galilee & 0 & 5 & 0 & 2 & 7 \\
\hline Valley of Esdraelon & 0 & 0 & 0 & 2 & 2 \\
\hline Central Jordan Valley & 0 & 0 & 1 & 2 & 3 \\
\hline Menashe Plateau & 4 & 0 & 0 & 0 & 6 \\
\hline Samarian Mountains & 0 & 7 & 1 & 1 & 9 \\
\hline Central Coastal Plain & 9 & 11 & 2 & 20 & 42 \\
\hline Judean Foothills & 11 & 3 & 2 & 9 & 25 \\
\hline Judean Mountains & 1 & 0 & 0 & 1 & 2 \\
\hline Southern Coastal Plain & 0 & 8 & 0 & 2 & 10 \\
\hline Northern Negev & 2 & 5 & 1 & 5 & 13 \\
\hline
\end{tabular}

${ }^{a}$ For data analyses, isolates from the following regions were combined: Valley of Esdraelon and Central Jordan Valley, Menashe Plateau and Samarian Mountains, and Judean Foothills and Judean Mountains.

${ }^{\mathrm{b}}$ Isolates from 1996 are not included in the total; in 1996, 26 isolates were collected at a site on the Menashe Plateau and 22 were collected from a site at Tel Aviv in the Central Coastal Plain. 
$P c-13$ from Clinton and $P c-24, P c-25$, and $P c-26$ from Garry (28). If these genes are present in X465 and other differentials with the same genetic background, we can conclude that none of these genes were effective against more than a few isolates of $P$. coronata from Israel.
Frequencies of virulence to the known $P c$ gene differentials in isolates from Israel in 1991, 1992, 1994, and 1996 were compared to frequencies of virulence in Texas and the Northern Plains of the United States. Statistically significant differences as determined by Fisher's exact test are shown in Table 5. Results from

TABLE 4. Frequencies of virulence in collections of Puccinia coronata from Texas and the Northern Plains of the United States

\begin{tabular}{|c|c|c|c|c|c|c|c|c|c|c|}
\hline \multirow[b]{3}{*}{ Differentials } & \multicolumn{10}{|c|}{ Percent isolates virulent } \\
\hline & \multicolumn{5}{|c|}{ Northern Plains ${ }^{a}$} & \multicolumn{5}{|c|}{ Texas } \\
\hline & 1991 & 1992 & 1993 & 1994 & 1996 & 1991 & 1992 & 1993 & 1994 & 1996 \\
\hline$P c-14$ & 86 & 94 & 95 & 84 & 70 & 84 & 93 & 91 & 94 & 67 \\
\hline Pc-35 & 38 & 55 & 31 & 46 & 28 & 70 & 71 & 83 & 74 & 28 \\
\hline$P c-36$ & 26 & 55 & 23 & 43 & 49 & 28 & 57 & 17 & 40 & 39 \\
\hline Pc-38 & 60 & 70 & 67 & 70 & 40 & 11 & 34 & 9 & 36 & 17 \\
\hline$P c-39$ & 47 & 61 & 52 & 54 & 44 & 3 & 25 & 9 & 26 & 17 \\
\hline$P c-40$ & 53 & 76 & 72 & 86 & 60 & 83 & 85 & 91 & 100 & 72 \\
\hline$P c-45$ & 0 & 3 & 7 & 4 & 5 & 15 & 19 & 9 & 6 & 44 \\
\hline$P c-46$ & 21 & 24 & 33 & 31 & 28 & 10 & 22 & 9 & 38 & 72 \\
\hline$P_{c-48}$ & 0 & 21 & 8 & 4 & 7 & 3 & 13 & 0 & 0 & 28 \\
\hline$P c-51$ & 48 & 55 & 59 & 50 & 39 & 74 & 73 & 87 & 76 & 83 \\
\hline$P c-52$ & 0 & 12 & 1 & 4 & 4 & 0 & 9 & 0 & 0 & 17 \\
\hline$P c-54$ & 12 & 39 & 23 & 13 & 7 & 21 & 56 & 9 & 47 & 39 \\
\hline$P c-55$ & 47 & 58 & 52 & 54 & 49 & 3 & 25 & 9 & 26 & 17 \\
\hline$P c-56$ & 15 & 70 & 23 & 48 & 49 & 36 & 59 & 30 & 50 & 61 \\
\hline$P c-57$ & 17 & 6 & 6 & 27 & 14 & 17 & 25 & 0 & 27 & 78 \\
\hline$P c-58$ & 0 & 24 & 6 & 11 & 7 & 27 & 39 & 13 & 35 & 17 \\
\hline$P c-59$ & 26 & 50 & 16 & 23 & 19 & 17 & 71 & 65 & 44 & 17 \\
\hline$P c-60$ & 31 & 72 & 50 & 81 & 19 & 62 & 83 & 87 & 89 & 61 \\
\hline$P c-61$ & 23 & 34 & 47 & 53 & 11 & 50 & 70 & 83 & 85 & 72 \\
\hline$P c-62$ & 2 & 15 & 4 & 4 & 2 & 2 & 2 & 0 & 0 & 6 \\
\hline$P c-63$ & 58 & 58 & 62 & 51 & 30 & 7 & 31 & 9 & 26 & 6 \\
\hline$P c-64$ & 5 & 18 & 5 & 6 & 2 & 2 & 11 & 0 & 6 & 6 \\
\hline$P c-67$ & 37 & 88 & 27 & 83 & 39 & 70 & 83 & 35 & 64 & 44 \\
\hline$P c-68$ & 0 & 0 & 2 & 1 & 0 & 0 & 1 & 0 & 20 & 0 \\
\hline$P c-70$ & 37 & 52 & 19 & 37 & 40 & 3 & 32 & 10 & 27 & 17 \\
\hline$P c-71$ & 44 & 61 & 49 & 51 & 49 & 1 & 24 & 5 & 26 & 17 \\
\hline No. of isolates & 43 & 33 & 120 & 136 & 57 & 105 & 101 & 23 & 47 & 18 \\
\hline
\end{tabular}

a Includes collections from Minnesota, North Dakota, and South Dakota.

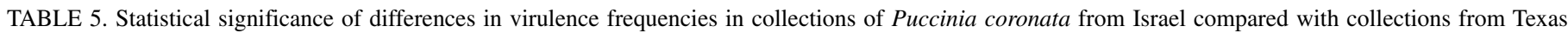
and the Northern Plains of the United States ${ }^{\mathrm{a}}$

\begin{tabular}{|c|c|c|c|c|c|c|c|c|c|c|c|c|}
\hline \multirow[b]{2}{*}{ Differentials } & \multicolumn{6}{|c|}{ Israel versus Northern Plains } & \multicolumn{6}{|c|}{ Israel versus Texas } \\
\hline & 1991 & 1992 & 1993 & 1994 & 1996 & All & 1991 & 1992 & 1993 & 1994 & 1996 & All \\
\hline Pc-14 & $\ldots$ & $\cdots$ & & $\cdots$ & & $\ldots$ & $\ldots$ & $\ldots$ & $\ldots$ & & $\cdots$ & $\ldots$ \\
\hline$P c-35$ & $\ldots$ & 0.043 & 0.039 & $\ldots$ & 0.000 & $\ldots$ & $\ldots$ & $\ldots$ & $\ldots$ & $(0.036)$ & 0.001 & $\ldots$ \\
\hline$P c-36$ & $\ldots$ & $\ldots$ & $\ldots$ & $(0.000)$ & $(0.000)$ & $\ldots$ & $\ldots$ & $\ldots$ & $\ldots$ & $(0.000)$ & $(0.003)$ & $\ldots$ \\
\hline$P c-38$ & $(0.000)$ & $(0.001)$ & $\ldots$ & $(0.006)$ & $\ldots$ & $(0.000)$ & $\ldots$ & $\ldots$ & $\ldots$ & $\ldots$ & $\ldots$ & $\ldots$ \\
\hline$P c-39$ & $\ldots$ & $\ldots$ & $\ldots$ & $\ldots$ & 0.000 & $\ldots$ & 0.000 & 0.004 & $\ldots$ & 0.000 & 0.000 & 0.000 \\
\hline Pc- 40 & $\ldots$ & 0.010 & $\ldots$ & 0.002 & 0.000 & $\ldots$ & $\ldots$ & $\ldots$ & $\ldots$ & $\ldots$ & 0.030 & $\ldots$ \\
\hline$P c-45$ & 0.000 & 0.000 & $\ldots$ & 0.000 & 0.000 & 0.000 & 0.025 & 0.000 & $\ldots$ & 0.000 & 0.000 & 0.025 \\
\hline$P c-46$ & 0.008 & 0.000 & $\ldots$ & 0.000 & 0.000 & 0.008 & 0.000 & 0.000 & 0.016 & 0.000 & 0.030 & 0.000 \\
\hline Pc-48 & 0.000 & 0.013 & $\ldots$ & 0.000 & 0.001 & 0.000 & 0.000 & 0.000 & $\ldots$ & 0.000 & 0.005 & 0.000 \\
\hline$P c-51$ & $\ldots$ & $\ldots$ & $\ldots$ & $(0.000)$ & $\ldots$ & $\ldots$ & $(0.004)$ & $\ldots$ & $(0.018)$ & $(0.000)$ & $(0.001)$ & $(0.004)$ \\
\hline$P c-52$ & 0.006 & $\ldots$ & $\ldots$ & 0.000 & 0.011 & 0.006 & 0.000 & $\ldots$ & $\ldots$ & 0.000 & $\ldots$ & 0.000 \\
\hline$P c-54$ & 0.000 & 0.015 & $\ldots$ & 0.000 & 0.000 & 0.000 & 0.000 & $\ldots$ & $\ldots$ & 0.000 & 0.000 & 0.000 \\
\hline$P c-55$ & $\ldots$ & $\ldots$ & $\ldots$ & $\ldots$ & 0.000 & $\ldots$ & 0.000 & 0.011 & $\ldots$ & 0.001 & 0.000 & 0.000 \\
\hline$P c-56$ & $\ldots$ & $(0.000)$ & $\ldots$ & $(0.000)$ & $(0.000)$ & $\ldots$ & $\ldots$ & $(0.000)$ & $\ldots$ & $(0.000)$ & $(0.000)$ & $\ldots$ \\
\hline$P c-57$ & $\ldots$ & 0.000 & $\ldots$ & 0.000 & 0.000 & $\ldots$ & $\ldots$ & 0.001 & $\ldots$ & 0.000 & $\ldots$ & $\ldots$ \\
\hline Pc-58 & 0.000 & 0.014 & $\ldots$ & 0.002 & 0.001 & 0.000 & $\ldots$ & $\ldots$ & $\ldots$ & $\ldots$ & $\ldots$ & $\ldots$ \\
\hline Pc-59 & 0.001 & 0.017 & $\ldots$ & $\ldots$ & $\ldots$ & 0.001 & 0.000 & $\ldots$ & $\ldots$ & $\ldots$ & $\ldots$ & 0.000 \\
\hline$P c-60$ & 0.001 & 0.018 & $\ldots$ & $(0.001)$ & 0.003 & 0.001 & $\ldots$ & $\ldots$ & $\ldots$ & $(0.000)$ & $\ldots$ & $\ldots$ \\
\hline$P c-61$ & $\ldots$ & 0.016 & $\ldots$ & $(0.005)$ & 0.000 & $\ldots$ & $\ldots$ & $\ldots$ & $\ldots$ & $(0.000)$ & $\ldots$ & $\ldots$ \\
\hline$P c-62$ & $\ldots$ & $\ldots$ & $\ldots$ & 0.000 & 0.000 & $\ldots$ & $\ldots$ & 0.010 & $\ldots$ & 0.000 & $\ldots$ & $\ldots$ \\
\hline$P c-63$ & $(0.000)$ & $(0.000)$ & (0.019) & $(0.000)$ & $(0.000)$ & $(0.000)$ & $\ldots$ & $(0.050)$ & $\ldots$ & $(0.001)$ & $\ldots$ & $\ldots$ \\
\hline$P c-64$ & $\ldots$ & 0.011 & 0.008 & 0.000 & 0.000 & $\ldots$ & 0.001 & 0.000 & 0.009 & 0.000 & 0.003 & 0.001 \\
\hline$P c-67$ & $\ldots$ & $(0.007)$ & $\ldots$ & $(0.000)$ & $\ldots$ & $\ldots$ & $(0.001)$ & $(0.005)$ & $\ldots$ & $\ldots$ & $\ldots$ & $(0.001)$ \\
\hline$P c-68$ & $\ldots$ & $\ldots$ & $\ldots$ & $\ldots$ & $\ldots$ & $\ldots$ & $\ldots$ & $\ldots$ & $\ldots$ & $(0.001)$ & $\ldots$ & $\ldots$ \\
\hline$P c-70$ & $\ldots$ & $\ldots$ & $\ldots$ & $\ldots$ & 0.001 & $\ldots$ & 0.000 & 0.005 & $\ldots$ & $\ldots$ & 0.000 & 0.000 \\
\hline$P c-71$ & 0.015 & $\ldots$ & $\ldots$ & $\ldots$ & $\ldots$ & 0.015 & 0.001 & 0.007 & $\ldots$ & $\ldots$ & 0.002 & 0.001 \\
\hline
\end{tabular}

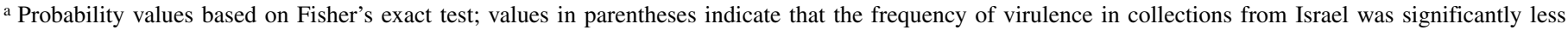
than frequencies in the indicated areas of the United States. For values not in parentheses, the frequency of virulence in Israel was significantly greater than that in the United States. 
the $\chi^{2}$ test, which are not shown, were similar except that the $\chi^{2}$ test was slightly more conservative, indicating slightly fewer statistically significant differences than Fisher's exact test. For the data combined over all years, isolates from Israel were significantly more virulent than those from the Northern Plains of the United States on differentials with $P c-45, P c-46, P c-48, P c-52$, $P c-54, P c-58, P c-59, P c-60$, and $P c-70$, and significantly less virulent on $P c-38$ and $P c-63$. Over all years, isolates from Israel were significantly more virulent than those from Texas on $P c-39$, $P c-45, P c-46, P c-48, P c-52, P c-54, P c-55, P c-59, P c-64, P c-70$, and $P c-71$, and significantly less virulent on $P c-51$ and $P c-67$. For each of the years 1991, 1992, 1994, and 1996, when adequate numbers of isolates were available, the isolates from Israel were significantly more virulent than isolates from the Northern Plains on differentials with $P c-45, P c-46, P c-48$, and $P c-58$ and significantly less virulent on $P c$ - 63 . For the same 4 years, isolates from Israel were significantly more virulent than isolates from Texas in each year on $P c-39, P c-45, P c-46, P c-48, P c-55$, and $P c-64$ and significantly less virulent on $P c-51$ (Table 5).

Collections of aecial isolates of $P$. coronata from the St. Paul buckthorn nursery in 1992 showed that isolates from both $R$. $\mathrm{ca}$ thartica and $R$. palaestina were polymorphic for virulence on all of the single $P c$ gene differentials except $P c-67$, which was susceptible to all the isolates, and $P c-68$, which was resistant to all the isolates (Table 6). On $P c-35$ and $P c-61$, the frequencies of virulence were significantly greater $(P<0.05)$ among isolates from $R$. palaestina than among isolates from $R$. cathartica; on other differentials, there were no significant differences. Thus, there was no evidence that susceptibility differences between $R$. palaestina and $R$. cathartica could account for the significant differences in virulence frequencies observed between collections

TABLE 6. Frequencies of virulence among aecial isolates of Puccinia coronata from Rhamnus cathartica and $R$. palaestina at St. Paul, $\mathrm{MN}$ in $1992^{\mathrm{a}}$

\begin{tabular}{|c|c|c|c|}
\hline \multirow[b]{2}{*}{ Differential } & \multicolumn{2}{|c|}{ Percent of isolates virulent } & \multirow[b]{2}{*}{ Probability ${ }^{\mathrm{b}}$} \\
\hline & R. cathartica & R. palaestina & \\
\hline Pc-14 & 100 & 97 & $\ldots$ \\
\hline$P c-35$ & 78 & 95 & 0.046 \\
\hline$P c-36$ & 92 & 89 & $\ldots$ \\
\hline Pc-38 & 86 & 83 & $\ldots$ \\
\hline Pc-39 & 75 & 67 & $\ldots$ \\
\hline Pc-40 & 94 & 89 & $\ldots$ \\
\hline$P c-45$ & 14 & 28 & $\ldots$ \\
\hline$P c-46$ & 47 & 68 & 0.100 \\
\hline Pc-48 & 36 & 46 & $\ldots$ \\
\hline$P c-51$ & 67 & 76 & $\ldots$ \\
\hline$P c-52$ & 25 & 38 & $\ldots$ \\
\hline Pc-54 & 61 & 49 & $\ldots$ \\
\hline$P c-55$ & 77 & 76 & $\ldots$ \\
\hline Pc-56 & 83 & 94 & $\ldots$ \\
\hline$P c-57$ & 14 & 27 & $\ldots$ \\
\hline Pc-58 & 42 & 59 & $\ldots$ \\
\hline Pc-59 & 55 & 65 & $\ldots$ \\
\hline$P c-60$ & 78 & 76 & $\ldots$ \\
\hline$P c-61$ & 28 & 65 & 0.002 \\
\hline$P c-62$ & 19 & 6 & $\ldots$ \\
\hline$P c-63$ & 83 & 76 & $\ldots$ \\
\hline$P c-64$ & 6 & 8 & $\ldots$ \\
\hline$P c-67$ & 100 & 100 & $\ldots$ \\
\hline Pc-68 & 0 & 0 & $\ldots$ \\
\hline Pc-70 & 67 & 66 & $\ldots$ \\
\hline$P c-71$ & 71 & 57 & $\ldots$ \\
\hline No. of isolates & 36 & 37 & $\ldots$ \\
\hline
\end{tabular}

a Potted plants of $R$. palaestina were exposed to natural inoculum from overwintered oat straw bearing telia of $P$. coronata adjacent to a hedge of $R$. cathartica bushes in the St. Paul buckthorn nursery in the spring of 1992. Aecial collections from $R$. cathartica were made adjacent to locations of $R$. palaestina plants.

b Probability of an equal difference occurring by random variation determined by Fisher's exact test. Probability values of $>0.1$ are not shown. of uredinial isolates from Israel and the Northern Plains of the United States.

Normalized virulence complexity was calculated for each isolate based on reactions on the 26 known single $P c$ gene differentials. For isolates from Israel, mean virulence complexity values calculated over the combination of 26 single $P c$ gene differentials plus the 11 backcross lines from the Iowa multiline program were similar to those calculated for just the $26 P c$ genes (data not shown). Mean virulence complexity was greater among isolates from Israel than from Texas or the Northern Plains of the United States in each year expect 1993, when only seven isolates were obtained from Israel (Table 7). Over all years, the difference between Israel and the Northern Plains was statistically significant $(P=0.040)$ but not between Israel and Texas, which is a reflection of the wide range in virulence complexity among isolates from each region.

The distributions of virulence complexity showed peak frequencies at intermediate levels of complexity in both Israel and the United States, but the peaks tended to be broader and at slightly higher levels of complexity in collections from Israel than from the United States (Fig. 2). The position of the peaks for isolates from A. sterilis from the Menashe Plateau and for isolates from A. sativa from Tel Aviv in 1996 were of similar shapes and at the same complexity level (data not shown).

To test the relationship between mean virulence complexity of isolates from different areas of Israel and the distribution of crown rust resistance in collections of $A$. sterilis from those areas, the data of Wahl (34) are presented with complexity data from this study in Table 8 . There was essentially no correlation between complexity of virulence in isolates of $P$. coronata from eight areas of Israel from the Northern Negev to Upper Galilee and the proportions of $A$. sterilis collections with the frequency of seedling resistance to race 264 of $P$. coronata in Wahl's tests. Thus, isolates of $P$. coronata from the Menashe Plateau, where Wahl (34) found the greatest proportion of sites and plants of A. sterilis with resistance to race 264 , did not show any greater virulence complexity than isolates from most other areas of the country.

\section{DISCUSSION}

Browning (3) emphasized the importance of studying indigenous host-pathogen systems in the centers of origin of cultivated plants to understand how disease resistance functions in nature. He argued that better understanding of resistance in natural hostpathogen systems could lead to more effective use of genes for resistance in cultivated crops. The Iowa oat multiline breeding

TABLE 7. Normalized mean virulence complexity for collections of Puccinia coronata from Avena sterilis in Israel and from A. sativa in Texas and the Northern Plains of the United States ${ }^{\mathrm{a}}$

\begin{tabular}{lccc}
\hline & \multicolumn{3}{c}{ Normalized virulence complexity } \\
\cline { 2 - 4 } Year & Israel & Northern Plains & Texas \\
\hline 1991 & 0.37 & 0.27 & 0.28 \\
1992 & 0.53 & 0.44 & 0.43 \\
1993 & 0.34 & 0.35 & 0.30 \\
1994 & 0.51 & 0.39 & 0.42 \\
$1996^{\mathrm{b}}$ & 0.50 & 0.26 & 0.37 \\
Mean $_{\text {Probability }}^{\mathrm{c}}$ & 0.45 & 0.34 & 0.36 \\
\hline
\end{tabular}

a Average number of virulences identified divided by the number of differentials tested; in these comparisons data for 25 differentials with known $P c$ genes were used. Data from $P c-55$ were excluded.

b For 1996 collections from Israel, data for isolates collected from A. sterilis were used and data for isolates from A. sativa were excluded.

c Probability of the null hypothesis that virulence complexity for collections from Israel was not greater than complexity for collections from the Northern Plains or Texas according to the one-tailed $t$ test. 
program was designed to stabilize races of $P$. coronata in the Midwest through the cultivation of mixtures of oat lines with different genes for race-specific resistance that would mimic the genetically mixed populations of wild oat in the center of origin of oats and oat crown rust. Studies in Israel clearly show that oligogenic resistance to crown rust in combination with polygenic partial resistance contributes to the stability of the A. sterilis and $P$. coronata pathosystem in Israel in the center of origin of oat and oat crown rust $(3,26,35)$. The oat crown rust pathosystem in Israel is typical of those described for obligate parasites in their centers of origin: there is extreme genetic diversity in the host with a multitude of resistance types that are matched by a broad range of specific virulence patterns in the pathogen population. In the long process of coevolution, selection pressures imposed by the pathogen on the host and by the host on the pathogen result in an accumulation of many resistance and virulence genes $(24,35)$.

This interpretation of host-parasite coevolution in the center of origin assumes conditions that prevent natural selection in indige-
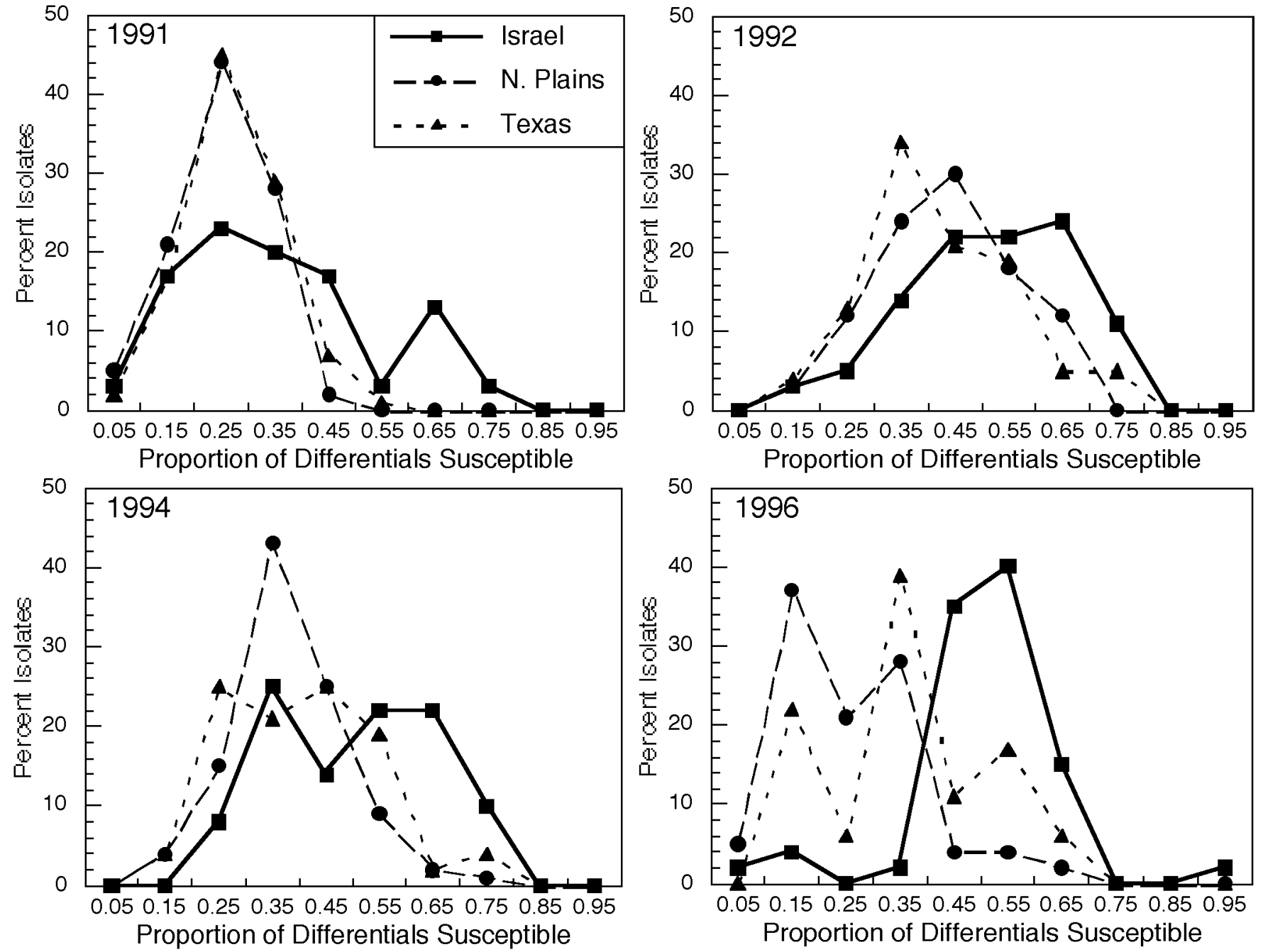

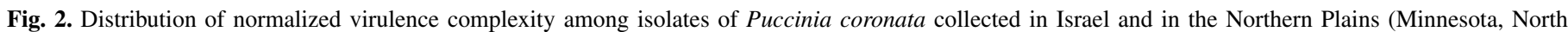

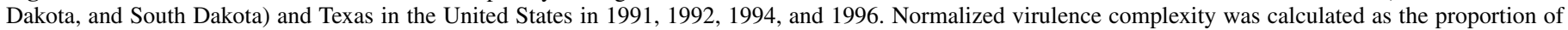
26 differentials with known single $P c$ genes for resistance on which each isolate was virulent.

TABLE 8. Mean virulence complexity of Puccinia coronata collections from regions of Israel compared with occurrence of seedling resistance to $P$. coronata in collections of Avena sterilis within the same regions (34)

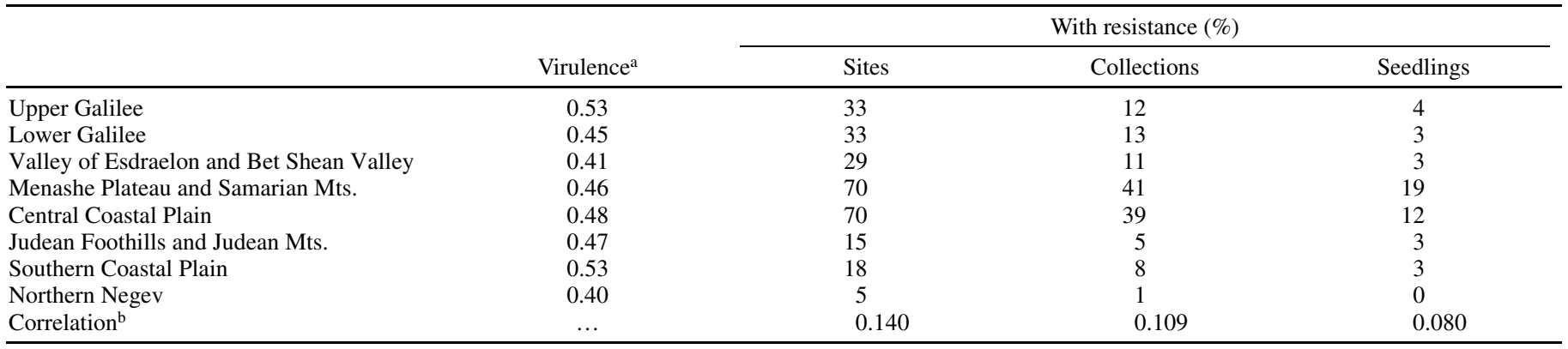

${ }^{a}$ Mean virulence complexity.

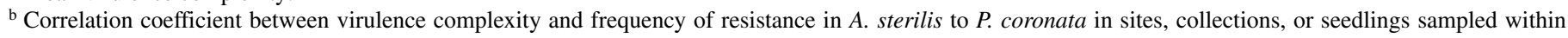
regions. Data for occurrence of resistance are from Wahl (34). 
nous host-parasite systems from proceeding unimpeded to fixation of specific genes for resistance in the host and, consequently, of corresponding virulence genes in the parasite. As evidence that such balancing conditions must exist, Wahl et al. (35) cited data showing that the prevalence of 'low-reaction' resistance to crown rust in A. sterilis populations in the Menashe Plateau in Israel remained unchanged during 17 years of study. This evidence, however, is not sufficient to conclude that the frequencies of individual resistance genes and virulence genes did not change over 17 years in that area. Individual resistance genes were not identified in the plants whose resistant phenotypes were noted, and individual virulence or avirulence genes were not identified in the pathogen isolates obtained from the host plants in those early studies. Therefore, the results of Wahl et al. (35) do not exclude the possibility that the relatively constant proportions of resistant plants in the A. sterilis population in the Menashe Plateau might have resulted from turnover of resistance genes. That is, new resistance genes might have arisen to replace 'defeated' genes whose effectiveness was lost due to increasing frequencies of the corresponding virulence genes in the $P$. coronata population. On the other hand, our data indicate that such a turnover of resistance genes is unlikely. The $P c$ genes in differentials used in this study were obtained from accessions of A. sterilis collected in the 1960s and 1970s, yet those $P c$ genes were still effective against a large proportion of the isolates of $P$. coronata collected in Israel 20 to 30 years later.

Surveys of virulence in $P$. coronata in Israel employed the Simons and Murphy (30) set of oat differentials with crown rust resistance genes derived from $A$. sativa $(2,33)$. Whether those resistance genes also occur in A. sterilis was not established. Thus, the virulence detected in those surveys was of unknown relevance to the resistance in the wild oat populations in Israel. Wahl (33) reported that the race 276-264-263 group made up $41 \%$ of the isolates of $P$. coronata from Israel tested in 1956 to 1959. Brodny (2) reported that races 276 and 264 were the most prevalent races in Israel from 1976 to 1980 . Race 276 is virulent on eight of the Simons and Murphy (30) differentials but avirulent on Victoria and Saia; race 263 is avirulent on Victoria, Ukraine, and Saia; and race 264 is avirulent only on Saia (29). Over the 5 years of his survey, Brodny (2) found that virulence ranged from 6 to $10 \%$ on Victoria, 16 to $22 \%$ on Landhafer, 16 to $21 \%$ on Santa Fe, 24 to $36 \%$ on Bond, 18 to $22 \%$ on Ukraine, and 1 to $3 \%$ on Saia. Frequencies of virulence on Anthony, Appler, Trispernia, and Bondvic were not reported by Brodny (2), but presumably those frequencies were high, because of the high frequencies reported for races 276 and 264. Wahl's (33) survey in 1956 to 1959 showed virulence on Bond, Landhafer, Santa Fe, Trispernia, and Bondvic at 70 to $71 \%$ each and virulence on Anthony and Appler at 94 and 98\%, respectively. Because Wahl grouped some races together, it was not possible to determine the frequencies of virulence on Victoria and Ukraine from data reported in his survey.

In the present study, we found race 264 to be the most common in Israel, making up 22 of 30 isolates in 1991, 33 of 42 in 1992, 4 of 7 in 1993, 16 of 48 in 1994, and 5 of 46 in 1996. We did not find race 276. All of our isolates from 1991, 1992, 1993, and 1996 were virulent on Victoria, which is resistant to race 276 . In general, we found frequencies of virulence to the Simons and Murphy (30) differentials to be similar to those found by Wahl (33) in 1956 to 1959 but higher than reported by Brodny (2) in 1976 to 1980, except for Saia, which was resistant to all of the isolates in Wahl's (33) survey, to 93 to $100 \%$ of the isolates in the 5 years of our survey, and to 97 to $99 \%$ of the isolates in the 5 years of Brodny's (2) survey. These data suggest that the frequencies of virulence to specific differentials may fluctuate considerably in the population of $P$. coronata in Israel over prolonged periods. This, however, does not necessarily contradict the conclusion that resistance or susceptibility and virulence or avirulence persist in balanced polymorphisms in indigenous hostpathogen systems $(24,35)$. Mathematical models of host-pathogen coevolution (17) show that, in balanced host-pathogen systems, the frequencies of genes for resistance and virulence may fluctuate considerably around their equilibrium frequencies. If the genes for crown rust resistance in the Simons and Murphy (30) differentials are part of a balanced system of polymorphism in the host population in Israel, those $P c$ genes, which so far are known only from $A$. sativa, also must occur in A. sterilis plants in the Mediterranean region. That seems likely, because A. sterilis is the progenitor of A. sativa (16). A. sativa may have retained some genes for resistance to crown rust from its wild progenitor.

Before the genes for crown rust resistance in most of Simons and Murphy's (30) differentials were used in breeding American oat cultivars for resistance to crown rust, the corresponding virulence genes were rare in North America. Up to 1955, few isolates of $P$. coronata from the United States were virulent to Landhafer, Santa Fe, Ukraine, Trispernia, Bondvic, or Saia, but more than half the isolates from the early 1950s were virulent on Anthony, Appler, and Bond (30). Virulence to Bond and Victoria was rare in the United States until the 1940s $(14,25)$. Virulence to Landhafer and Santa Fe did not become common in the United States until the 1960s (21). On the other hand, races virulent to all the Simons and Murphy (30) differentials except Saia long have been common in Israel, where there has been little commercial oat production. Apparently, the earliest introductions of $P$. coronata into North America lacked much of the virulence commonly found in indigenous populations in Israel.

On average, isolates of $P$. coronata were significantly more virulent to differentials with resistance genes from $A$. sativa sources than to differentials with $P c$ genes from accessions of A. sterilis collected in Israel. These isolates also were more virulent on average to differentials with $P c$ genes from Israel than to differentials with $P c$ genes from A. sterilis collected in other countries around the Mediterranean region, as would be expected from natural selection in the $P$. coronata populations within Israel. The higher virulence in Israel to differentials with $P c$ genes from $A$. sativa than from $A$. sterilis accessions from Israel suggests either that the $P c$ genes from $A$. sativa are very weak genes or that they are also common in A. sterilis as well as in A. sativa. Weak resistance genes as defined by Vanderplank (32) are those for which there is little or no balancing selection to prevent the corresponding virulence from becoming fixed in the pathogen population. Data for 1994 and 1996 show that virulence frequencies for six of the A. sativa differentials fell to less than $90 \%$, which would not be expected if balancing selection were completely ineffective. If the $P c$ genes that have been identified from $A$. sativa sources are not very weak genes, it seems likely that they must be present in A. sterilis as well as in A. sativa.

Virulence frequencies in the populations of $P$. coronata from Texas and the Northern Plains of the United States did not consistently occur at $>90 \%$ for any of the known single $P c$ gene differentials over the 5-year period, even though cultivars with $P c-58, P c-59, P c-60$, and $P c-61$ were used extensively in Texas and other southern states in the 1970s and 1980s $(6,10)$, and cultivars with $P c-38$ and $P c-39$ were used extensively in the Northern Plains in the 1980s and early 1990s (6). This suggests that some type of balancing selection occurs in the agricultural host-pathogen system to interfere with fixation of virulence except in extreme cases of directional selection by overwhelming use of resistant cultivars. At least, this seems to be the case with virulence genes that correspond to the $P c$ genes that have been introduced to cultivated oat from $A$. sterilis (18).

Balancing selection appears to function also in the $P$. coronata population in Israel. Many of the differentials used in this study have $P c$ genes derived from accessions of $A$. sterilis that were collected from Israel in the 1960s and 1970s; therefore, those genes are known to have been have been present at detectable 
levels in A. sterilis in Israel for at least 20 to 30 years before the isolates used in this survey were obtained. If Wahl et al (35) and Mundt and Browning (24) are correct, those $P C$ genes have been in the A. sterilis populations of Israel for a much longer time, perhaps thousands of years. However, directional selection for virulence imposed by those $P c$ genes has not been sufficient to cause any of them to become fixed in the $P$. coronata population.

It is interesting that virulence to many of the $P c$ genes from A. sterilis that have been used sparingly or not at all in the United States up to the time of this survey is already present in the $P$. coronata populations of both Texas and the Northern Plains. $P c-36, P c-46, P c-51, P c-52, P c-57$, and $P c-71$ were used in Iowa multline cultivars released in the 1980s (11), but it is not likely that such use would have caused strong selection of corresponding virulence genes in $P$. coronata throughout the Northern Plains and, especially, not in Texas. Other genes, such as $P c-35, P c-40$, $P c-45, P c-46, P c-54, P c-56, P c-64$, and $P c-67$, are not recorded in oat cultivars grown commercially in the United States. The genes $P c-48, P c-62$, and $P c-68$ have been used in recent years in oat breeding in Manitoba and North Dakota, but that use would not have affected selection in $P$. coronata before the mid-1990s. The presence of virulence to most of these genes at levels between 10 and $80 \%$ indicates either that there is no strong selection against unnecessary virulence in the cultivated host-pathogen system or that some type of balancing selection helps to maintain these virulence genes in the $P$. coronata population near some intermediate equilibrium levels.

If there are equilibrium frequencies for virulence genes in $P$. coronata in the absence of the corresponding resistance genes in the host, then directional selection for virulence in the wild host-pathogen system in Israel should result in somewhat higher frequencies of virulence, at least for those genes corresponding to $P c$ genes known to occur in A. sterilis in Israel. Thus, it is interesting that, on average over the 5-year period of this study, the frequencies of virulence to $P c-35, P c-39, P c-45, P c-46, P c-48$, $P c-52, P c-54, P c-58, P c-59, P c-60$, and $P c-71$ were significantly higher in Israel than in the Northern Plains, and the frequencies of virulence to $P c-39, P c-45, P c-46, P c-48, P c-52, P c-54, P c-55$, $P c-59, P c-64, P c-70$, and $P c-71$ were higher in Israel than in Texas. The significantly greater frequency of virulence to $P c-38$ in the Northern Plains than in Israel may be attributed to greater directional selection imposed by extensive use of $P c-38$ in oat cultivars grown in the Northern Plains, although it should be noted that similar extensive use of $P c-39$ in the Northern Plains did not result in higher virulence than in the wild population in Israel. The greater virulence to $P c-63$ in the Northern Plains than in Israel may be attributed to the strong association of virulence to $P c-63$ and virulence to $P c-38$ (6). The greater frequency of virulence to $P c-36$ in the Northern Plains than in Israel has no obvious explanation. Also, frequencies of virulence to $P c-51$ and $P c-67$ were higher in Texas than in Israel, although there appears to be no clear reason for that.

It is unlikely that the difference in alternate hosts in the United States and Israel contributed to differences in virulence between the cultivated and wild host-pathogen systems. Neither $R$. cathartica nor $R$. palaestina excluded either virulence or avirulence to any of the differentials used in these tests, except possibly $P c-68$, for which no virulence was found in the aecial isolates from Minnesota or the uredinial isolates from Israel. Frequencies of virulence to nearly all of the single $P c$ gene differentials were greater among aecial isolates collected in 1992 from the St. Paul buckthorn nursery than among uredinial isolates collected in 1992 from oat fields in the Northern Plains. This likely was due to the higher prevalence of $P c$ genes in oat lines grown for testing in the buckthon nursery than in commercial oat cultivars in fields from which the uredinial isolates were obtained in this study. Comparisons of virulence in uredinial isolates from cultivated oat fields and aecial isolates from $R$. cathartica plants in natural habitats in
Minnesota in 1994 and 1995 showed no significant differences in frequencies of virulence between the aecial and uredinial isolates, except for virulence to the $P c-45$ differential, which was significantly greater among aecial isolates than uredinial isolates (18).

Mean virulence complexity among collections of $P$. coronata from eight areas of Israel from the Northern Negev to Upper Galilee was not significantly correlated with the abundance of seedling resistance among collections of $A$. sterilis reported by Wahl (34). Wahl (34) found the greatest abundance of collection sites with resistance and the highest frequency of seedlings with resistance to race 264 of $P$. coronata in the Menashe Plateau and in the Central Coastal Plain of Israel. The mean virulence complexity of isolates from these areas may have been greater than that of isolates from the Northern Negev and the Valley of Esdraelon, but the virulence complexity of isolates from the Menashe Plateau and the Central Coastal Plain was not greater than that of isolates from Upper Galilee and the Southern Coastal Plain, which showed relatively little crown rust resistance in Wahl's (34) collections of A. sterilis. It seems likely that migration of the highly mobile crown rust fungus is sufficient within Israel to blend out differences in virulence complexity between areas with high and low frequencies of resistant host plants. In Leonard's (17) mathematical model of host-pathogen coevolution, even relatively low rates of pathogen migration between high and low disease hazard sites served to stabilize equilibrium conditions for avirulence/virulence and susceptibility/resistance polymorphisms.

The range of virulence complexity among isolates of $P$. coronata from Israel showed a broader peak than occurred among isolates from cultivated oat in Texas and the Northern Plains of the United States. This may reflect the blending of isolates from a broader range of habitats in the natural A. sterilis- $P$. coronata pathosystem in Israel than in the agricultural A. sativa-P. coronata pathosystems of the United States. Natural host populations generally exist as a collection of metapopulations, each with unique combinations of genotypes on which the pathogen must compete (4), whereas host populations and habitats in agricultural systems tend to be much more homogeneous. This may lead to more consistent balancing selection for unnecessary virulences in the agricultural pathosystems and a narrower peak in the distribution of virulence complexity around some overall optimal level for the conditions of the host-pathogen interaction. In the natural pathosystem of $A$. sterilis and $P$. coronata, it is likely that high virulence complexity will be favored strongly in some habitats, whereas isolates with low virulence complexity will compete successfully in others.

The efficacy of mixtures of resistant cultivars or multiline varieties for control of diseases caused by obligate parasites has been amply demonstrated (36). Aside from marketing concerns for crop purity, one of the main arguments against the use of such mixtures has been that they might facilitate stepwise increase in virulence, leading to predominance of super races of the pathogen that combine virulence to all of the resistance genes. Browning and others $(3,24)$ cited examples of indigenous pathosystems, especially the oat crown rust pathosystem in Israel, as strong evidence that mixed host populations do not select for super races. Our results amplify and strengthen the case against selection of super races by mixed host populations. We found virulence or avirulence to be polymorphic in $P$. coronata in Israel for 35 of the 36 differentials with resistance genes from A. sterilis. The only exception was the $P c-68$ differential, for which virulence was not found. Even excluding cases of highly associated virulences to $P c-38$ and $P c-63$ and to $P c-39$ and $P c-55$, this indicates a remarkably high level of diversity for virulence in indigenous populations of $P$. coronata within the small country of Israel. Virulence frequencies varied widely for these differentials. On average, isolates collected from Israel were virulent to 41 to $55 \%$ of these 26 differentials over the years 1991, 1992, 1994, and 1996. In 
every year, some isolates were virulent on $<20 \%$ of the differentials and others were virulent on $>70 \%$ of the differentials. Thus, the potential for production of super races is present in the indigenous population of $P$. coronata on $A$. sterilis and $R$. palaestina in Israel, but super races do not dominate there. This is more remarkable in view of the relative abundance of virulence that apparently is unnecessary in the $P$. coronata populations on cultivated oat in the United States.

\section{ACKNOWLEDGMENTS}

We thank G. Ochocki for excellent technical assistance in isolating, maintaining, and testing cultures of $P$. coronata.

\section{LITERATURE CITED}

1. Bonnett, D. G. 1996. Host:pathogen studies of oat leaf rust in Australia. $\mathrm{Ph} . \mathrm{D}$. thesis. University of Sydney, Australia.

2. Brodny, U. 1988. Physiologic races of oat crown rust identified in Israel during 1976-1988. Can. J. Plant Pathol. 10:53-56.

3. Browning, J. A. 1974. Relevance of knowledge about natural ecosystems to development of pest management programs for agro-ecosystems. Proc. Am. Soc. Phytopathol. 1:191-199.

4. Burdon, J. J. 1997. The evolution of gene-for-gene interactions in natural pathosystems. Pages 245-262 in: The Gene-for-Gene Relationship in Plant-Parasite Interactions. I. R. Crute, E. B. Holum, and J. J. Burdon, eds. CAB International, Wallingford, UK.

5. Chong, J. 1984. Virulence and distributions of Puccinia coronata in Canada in 1983. Can. J. Plant Pathol. 6:249-252.

6. Chong, J., and Kolmer, J. A. 1993. Virulence dynamics and phenotypic diversity of Puccinia coronata f. sp. avenae in Canada from 1974 to 1980. Can. J. Bot. 71:248-255.

7. Fleischmann, G., and McKenzie, R. I. H. 1968. Inheritance of crown rust resistance in Avena sterilis. Crop Sci. 8:710-713.

8. Fleischmann, G., McKenzie, R. I. H., and Shipton, W. A. 1971. Inheritance of crown rust resistance in Avena sterilis L. from Israel. Crop Sci. 11:451-454.

9. Fleischmann, G., McKenzie, R. I. H., and Shipton, W. A. 1971. Inheritance of crown rust resistance genes in Avena sterilis collections from Israel, Portugal, and Tunisia. Can. J. Genet. Cytol. 13:251-255.

10. Frey, K. J. 1991. Genetic resources of oats. Pages 15-24 in: Use of Plant Introductions in Cultivar Development, Part 1. H. L. Shands and L. E. Wiesner, eds. Crop Sci. Soc. Am. Spec. Publ. No. 17.

11. Frey, K. J., Simons, M. D., Michel, L. J., Murphy, J. P., and Browning, J. A. 1988. Registration of 'Webster' oat. Crop Sci. 28:374-375.

12. Harder, D. E., McKenzie, R. I. H., and Martens, J. W. 1980. Inheritance of crown rust resistance in three accessions of Avena sterilis. Can. J. Genet. Cytol. 22:27-33.

13. Hickman, J. C. 1993. The Jepson Manual: Higher Plants of California. University of California Press, Berkeley.

14. Kehr, W. R., Hayes, H. K., Moore, M. B., and Stakman, E. C. 1950. The present status of breeding rust resistant oats at the Minnesota Station. Agron. J. 42:356-369.

15. Kiehn, F. S., McKenzie, R. I. H., and Harder, D. E. 1976. Inheritance of resistance to Puccinia coronata avenae and its associations with seed characteristics in four accessions of Avena sterilis Can. J. Genet. Cytol. 18:717-726.
16. Leggett, J. M., and Thomas, H. 1995. Oat evolution and cytogenetics. Pages 120-149 in: The Oat Crop: Production and Utilization. R. W. Welch, ed. Chapman \& Hall, London.

17. Leonard, K. J. 1997. Modeling gene frequency dynamics. Pages 211-230 in: The Gene-for-Gene Relationship in Host-Parasite Interactions. I. A. Crute, J. J. Burdon, and E. B. Holum, eds. CAB International, Wallingford, UK.

18. Leonard, K. J. 2003. Regional frequencies of virulence in oat crown rust in the United States from 1990 through 2000. Plant Dis. 87:1301-1310.

19. Lowry, R. 2003. VassarStats: Website for statistical computation. Appendix 8a. The Fisher's Exact Probability Test. Published online by Vassar College.

20. McKenzie, R. I. H., and Fleischmann, G. 1964. The inheritance of crown rust resistance in selections from two Israeli collections of Avena sterilis. Can. J. Genet. Cytol. 6:232-236.

21. Michel, L. J., and Simons, M. D. 1977. Aggressiveness and virulence of Puccinia coronata avenae isolates, 1971-1975. Plant Dis. Rep. 61:621625 .

22. Michel, L. J., and Simons, M. D. 1983. Virulence of Puccinia coronata in relation to available genes for resistance in oats. Plant Dis. 67:197-200.

23. Michel, L. J., and Simons, M. D. 1985. Registration of oat germplasms IA H676, IA H677, and IA H681 resistant to the oat crown rust fungus. Crop Sci. 25:716-717.

24. Mundt, C. C., and Browning, J. A. 1985. Genetic diversity and cereal rust management. Pages 527-560 in: The Cereal Rusts vol. II. A. P. Roelfs and W. R. Bushnell, eds. Academic Press, Orlando, FL.

25. Murphy, H. C., Stanton, T. R., and Coffman, F. A. 1942. Breeding for disease resistance in oats. J. Am. Soc. Agron. 34:72-89.

26. Segal, A., Manisterski, J., Fischbeck, G., and Wahl, I. 1980. How plant populations defend themselves in natural ecosystems. Pages 75-102 in: Plant Disease: An Advanced Treatise, vol. 4. J. G. Horsfall and E. B. Cowling, eds. Academic Press, Orlando, FL.

27. Simons, M. D. 1970. Crown rust of oats and grasses. Am. Phytopathol. Soc. Monogr No. 5. Heffernan Press, Worcester, MA.

28. Simons, M. D., Martens, J. W., McKenzie, R. I. H., Nishiyama, I., Sadanaga, K., Sebesta, J., and Thomas, H. 1978. Oats: A standardized system of nomenclature for genes and chromosomes and catalog of genes governing characters. U.S. Dep. Agric. Agric. Handb. no. 509.

29. Simons, M. D., and Michel, L. J. 1964. International register of pathogenic races of Puccinia coronata var. avenae. Plant Dis. Rep. 48:763-766.

30. Simons, M. D., and Murphy, H. C. 1955. A comparison of certain combinations of oat varieties as crown rust differentials. U.S. Dep. Agric. Tech. Bull. 1112.

31. Steel, R. G. D., and Torrie, J. H. 1960. Principles and Procedures of Statistics. McGraw-Hill, New York.

32. Vanderplank, J. E. 1968. Disease Resistance in Plants. Academic Press, Orlando, FL.

33. Wahl, I. 1959. Physiological races of oat crown rust identified in Israel in 1956-59. Bull. Res. Counc. Isr. 8D:25-30.

34. Wahl, I. 1970. Prevalence and geographic distribution of resistance to crown rust in Avena sterilis. Phytopathology 60:746-749.

35. Wahl, I., Anikster, Y., Manisterski, J., and Segal, A. 1984. Evolution at the center of origin. Pages 39-77 in: The Cereal Rusts, vol. I. W. R. Bushnell and A. P. Roelfs, eds. Academic Press, Orlando, FL.

36. Wolfe, M. S. 1985. The current status and prospects of multilane cultivars and varietal mixtures for resistance. Annu. Rev. Phytopathol. 23:251-273.

37. Wong, L. S. L., McKenzie, R. I. H., Harder, D. E., and Martens, J. W. 1983. The inheritance of resistance to Puccinia coronata and of floret characters in Avena sterilis. Can. J. Genet. Cytol. 25:329-335. 